\title{
Using Sodium Carbonate to Seal Leaky Stock Ponds in Eastern Montana
}

EARL L. NEFF

\begin{abstract}
Mixing sodium carbonate into the top 100 to $150 \mathrm{~mm}$ of soil in three farm ponds constructed in calcareous soil in eastern Montana effectively reduced seepage losses for about 3 years following treatment. Seepage rates the first year after treatment were decreased to 20 to $40 \%$ of the pretreatment rate, but they were 60 to $100 \%$ of the pretreatment rate 4 years after treatment.
\end{abstract}

Efficient livestock utilization of rangeland forage resources requires that stock water be distributed over the grazing area and available in sufficient quantity to last the entire grazing season. In arid and semiarid grazing regions, where natural lakes, ponds, and streams do not provide season-long water supplies, it has become a standard practice to construct artificial water impoundments like dugouts and small dams. The capacity of each constructed pond is usually less than $6,000 \mathrm{~m}^{3}$ and ponds are distributed to provide easy access to water throughout the pasture system. Most water in stock ponds is lost by evaporation and seepage with only a very small fraction actually used by livestock.

Various methods have been used to reduce losses by controlling both evaporation and seepage. For reducing evaporation, floating monomolecular films of long-chain, fatty alcohols (Roberts 1958; Roberts 1959; U.S. Bureau of Reclamation 1958), floating barriers of plastic spheres and blocks, and floating films of low melting-point wax (Cooley and Myers 1973; Cooley 1975) have been tested. Floating covers of foamed rubber and low melting point wax have successfully reduced evaporation by as much as $90 \%$ on small tanks (11m diameter, or smaller), but they have not been used on lakes or ponds. On larger lakes or ponds, monomolecular layers successfully reduce evaporation by only about $20 \%$ - primarily because wind action breaks the film and exposes free water to the evaporative processes. Seepage has been reduced with varying degrees of success by installing physical barriers like concrete and asphalt on reservoir soil surfaces (Dedrick 1975); flexible membranes, like sheet plastic and sheet rubber, buried beneath reservoir soil surfaces (Dedrick 1975; Laing 1975); or clay material, like bentonite, placed and compacted on reservoir soil surfaces (Dedrick 1975; Jamison and Thornton 1963; Laing 1975). Disadvantages of these seepage control measures are either the cost of materials and labor for initial installation and maintenance or the mechanical damage caused by weather, frost, and wild and domestic livestock.

Author is research hydraulic engineer, U.S. Dep. Agr., Science and Education Administration, Agricultural Research, Northern Plains Soil and Water Research Center, P.O. Box 1109, Sidney, Montana 59270.

This research is a contribution from the U.S. Dep. Agr. Science and Education Administration, Agr. Res., in cooperation with the Montana Agr. Exp. Sta. Journal Series No. 691 .

Manuscript received February 1, 1979
Several researchers (Dedrick 1975; Jamison and Thornton 1963; Laing 1975; Reginato et al. 1968; Reginato et al. 1973) have tried to decrease seepage with soil chemical treatments using various sodium compounds including sodium chloride, sodium carbonate, and sodium polyphosphates. Sodium in these compounds replaces the calcium and magnesium cations on the exchange complex causing the soil aggregates to disperse and the clay colloids to swell, thus sealing soil pores through which water seeps (Nakayama 1966). Sodium carbonate was an effective sealant in Arizona studies, because this salt provided not only sodium cations necessary for soil dispersion but also carbonate anions, which combined with calcium and magnesium and precipitated as insoluble salts (Nakayama 1966; Reginato et al. 1973). Seepage in these study ponds was drastically reduced after initial sodium carbonate treatment, but it gradually increased to an undesirable rate in about 3 years as calcium and magnesium in runoff water replaced sodium applied in the treatment. At this time, seepage was reduced to the immediate post-treatment rate by broadcasting a mixture of sodium carbonate and sodium chloride on the water surface.

Seepage rates in stock ponds in eastern Montana range from less than $7 \mathrm{~mm} /$ day to more than $30 \mathrm{~mm} /$ day. The ponds where seepage exceeds $15 \mathrm{~mm} /$ day generally become dry in late summer or early fall before livestock can efficiently utilize available rangeland forage. A low-cost method of sealing leaky stock would extend the available water supply into the fall and provide an economical opportunity for better forage usc.

A mail survey of all farm owners and operators in Sheridan County, Montana, provided an estimate of 800 to 900 stock ponds within the county. Nearly two-thirds of the ponds were classified as having poor and fair seepage rates, an indication of the number of ponds in this county alone that might benefit from an effective, low-cost sealing method.

\section{Methods}

The study reported here was conducted near Plentywood, Sheridan County, Montana. The climate is semiarid, continental, characterized by warm summers and cold, relatively dry winters. Average annual precipitation is about $340 \mathrm{~mm}$ with $80 \%$ occurring during the summer and $20 \%$ during winter. Although only $20 \%$ of the total, winter precipitation is extremely important because snowmelt is the primary source of water for stock ponds (Wight et al. 1975). Annual evaporation from lakes and ponds in the area averages about $960 \mathrm{~mm}$, and about $83 \%$, or $800 \mathrm{~mm}$ ( $4 \mathrm{~mm} /$ day), occurs in May through October (U.S. Weather Bureau 1959). The topography of the area is undulating glacial till plains. Small ridges and valleys occur alternately over short distances. Height of ridges above the valleys ranges from less than 3 to more than $30 \mathrm{~m}$. Soils 


\begin{tabular}{|c|c|c|c|c|c|c|c|c|c|c|}
\hline \multirow[b]{2}{*}{ Pond } & \multirow{2}{*}{$\begin{array}{l}\text { Drainage } \\
\text { area }\end{array}$} & \multirow{2}{*}{$\begin{array}{l}\text { Maximum } \\
\text { capacity }\end{array}$} & \multirow{2}{*}{$\begin{array}{c}\text { Maximum } \\
\text { depth }\end{array}$} & \multirow{2}{*}{$\begin{array}{c}\text { Surface } \\
\text { area }\end{array}$} & \multirow{2}{*}{$\begin{array}{l}\text { Storage } \\
\text { ratio }\end{array}$} & \multicolumn{3}{|c|}{ Soil texture } & \multicolumn{2}{|c|}{$\begin{array}{l}\text { Cation exchange } \\
\text { capacity }\end{array}$} \\
\hline & & & & & & $\%$ Sand & $\%$ Silt & $\%$ Clay & Average & Range \\
\hline & Hectare & $\mathrm{m}^{3}$ & $\mathrm{~m}$ & Hectare & \multicolumn{2}{|c|}{ Drain Area/Cap. } & & & \multicolumn{2}{|c|}{ Meq/ 100 g soil } \\
\hline Wagner & 109 & 2,500 & 2.1 & 0.29 & .044 & 39 & 29 & 32 & 37.4 & $28-45$ \\
\hline Nikolaisen C & 140 & 4,400 & 3.0 & 0.36 & .032 & 34 & 34 & 32 & 23.2 & $12-36$ \\
\hline Carlson & & 15,400 & 4.2 & 0.93 & & 36 & 32 & 32 & 25.1 & $14-34$ \\
\hline Morstad & $234^{*}$ & 9,100 & 2.7 & 0.81 & $.010^{*}$ & 37 & 33 & 30 & 29.8 & $14-45$ \\
\hline Nikolaisen A & 53 & 5,100 & 2.9 & 0.39 & .010 & 23 & 33 & 44 & 29.0 & $18-40$ \\
\hline
\end{tabular}

* Carlson and Morstad ponds are in tandem on the same channel. The Carlson dam is about $0.4 \mathrm{~km}$ downstream from the Morstad dam.

are predominately of the Zahill series, which is a member of the fine-loamy, mixed, calcareous, frigid family of Typic Ustorthents. The principal land use is range, interspersed with fields of small grain. Pond water in the area contains about $30 \mathrm{ppm}$ total dissolved salts, of which 4 ppm is sodium.

Five ponds, each with a different average seepage rate and with no history of previous soil treatments, were selected for study. Pond characteristics are listed in Table 1. Topographic surveys of the ponds were completed in 1971, and soil samples were taken at each intersection of a 7.6- by $15.2-\mathrm{m}$ grid system in the reservoir area of each pond. These soil samples were used to determine soil texture and cation exchange capacity. In addition, a bulk soil sample was taken from the Carlson pond for laboratory permeameter studies. Texture of the bulk soil sample was about $1 / 3$ each of sand, silt, and clay; cation exchange capacity (CEC) was $34 \mathrm{meq} / 100 \mathrm{~g}$ of soil, and exchangeable sodium was very low $(<0.25 \mathrm{meq} / 100 \mathrm{~g})$. Constant head permeameters with disturbed soil columns $152 \mathrm{~mm}$ in diameter and $152 \mathrm{~mm}$ long were used to determine basic seepage rates with different rates of sodium carbonate applied to the soil surface (Fig. 1). These data indicated that 6.7 metric tons/hectare sodium carbonate was the optimum for achieving maximum seepage reduction at minimum initial cost. After the permeameter runs were completed, the exchangeable sodium percentage (ESP) was $14 \%$ in the columns treated with 6.7 metric tons/hectare of sodium carbonate. These results compared favorably with the method recommended in Arizona studies (Reginato et al. 1973) which used the formula:

where:

$$
\mathrm{Na}_{2} \mathrm{CO}_{3}=0.004 \mathrm{DA}(0.15 \mathrm{CEC}-\mathrm{ES})
$$

$\mathrm{Na}_{2} \mathrm{CO}_{3}=$ sodium carbonate required (in pounds), $\mathrm{D}=$ depth to be treated (in inches),

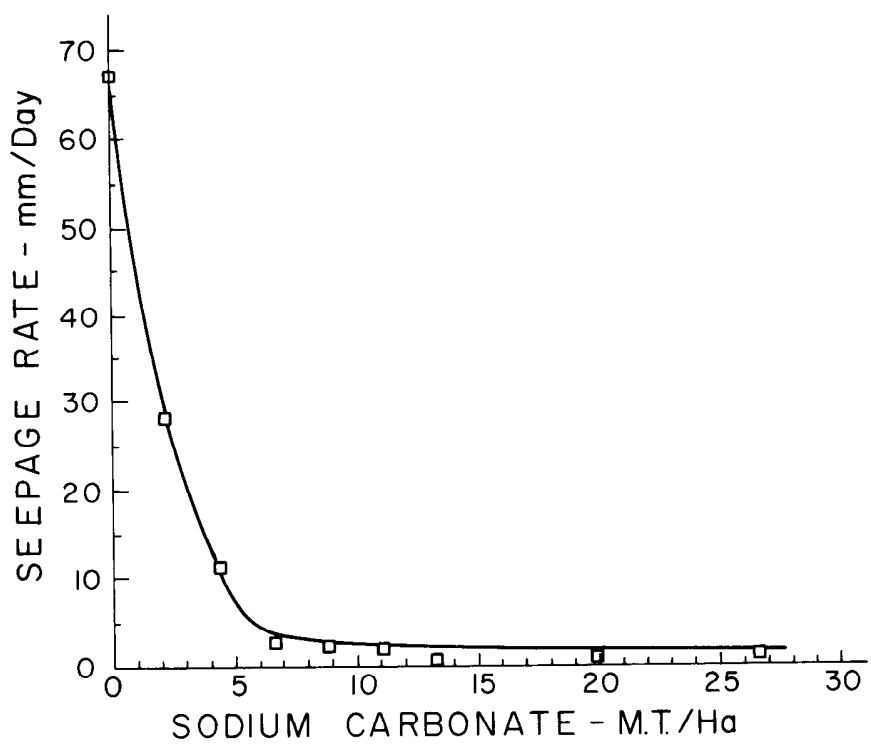

Fig. 1. Constant head pereameter results of seepage rate vs. sodium carbonate application rate.
$A=$ area to be treated (in acres),

$\mathrm{CEC}=$ cation exchange capacity (in meq/ $100 \mathrm{~g}$ soil), $\mathrm{ES}=$ exchangeable sodium (in meq/ $100 \mathrm{~g}$ soil).

Using equation [1] with the characteristics of the permeameter soil columns resulted in a recommended application rate of 2.7 tons/acre (6.0 metric tons/hectare) of sodium carbonate to achieve an ESP of $15 \%$.

Pond water levels were monitored weekly during the summer from 1972 through 1974 to determine normal seepage rates. Seepage between measurement periods was defined as the change in water depth minus pond evaporation plus precipitation. Pond evaporation was determined by applying a pan coefficient of 0.7 to data from a Class A Weather Bureau evaporation pan (U.S. Weather Bueau 1959). Data from periods during which surface runoff entered the ponds were not used to determine seepage rates. Seepage is a function not only of the soil physical and chemical characteristics but also of the water depth above the soil surface. To eliminate the effects of hydraulic head and compare ponds with different geometry, the seepage rate at $2 \mathrm{~m}$ water depth was used for each pond. Spring runoff in 1973 and 1977 did not fill the ponds to the 2-m stage, therefore, no records of seepage rates are available for these years.

Wagner, Nikolaisen $\mathrm{C}$, and Carlson ponds were treated in November 1974, with sodium carbonate at 6.7 metric tons/reservoir surface hectare. The reservoir area below spillway elevation was first disked to a 100 - to $150-\mathrm{mm}$ depth. Sodium carbonate was then spread with a tractor-drawn fertilizer spreader adjusted to dispense 1.68 metric tons/hectare (Fig. 2). Four passes were made to apply the design rate, and the area was disked once more to mix the sodium carbonate with the soil. The surface soil was not compacted after the final disking.

On all treated ponds, 6.7 metric tons/ hectare sodium carbonate was applied, which was an arbitrary decision dictated by an impending snow storm which precluded taking the time necessary to adjust and calibrate the spreader for each pond separately. This rate, according to equation [1], treated the areas with the highest CEC values in Wagner pond to a $125-\mathrm{mm}$ depth; in Nikolaisen C pond to a $150-\mathrm{mm}$ depth; and in Carlson pond to a $180-\mathrm{mm}$ depth. Treating the ponds for the highest CEC values reduced the possibility of leaky "holes" in the treatment blanket.

Morstad and Nikolaisen A ponds were left untreated. In the initial pond selection, these two were subjectively classified as "good" by the farm operators. I assumed that successful treatment would reduce the seepage rates at the three leaky ponds to values comparable with those natural seepage rates in the two untreated ponds (Table 2).

\section{Results}

All ponds were filled to (or near) spillway elevation during the spring runoff in 1975,1976 , and 1978. The untreated ponds had a total loss (evaporation plus seepage) pattern that was similar in these three posttreatment years to the pretreatment pattern. The 1975, 1976, and 1978 stage vs. time curves for the Nikolaisen A and the Morstad pond paralleled those from the pretreatment years. Since normal 


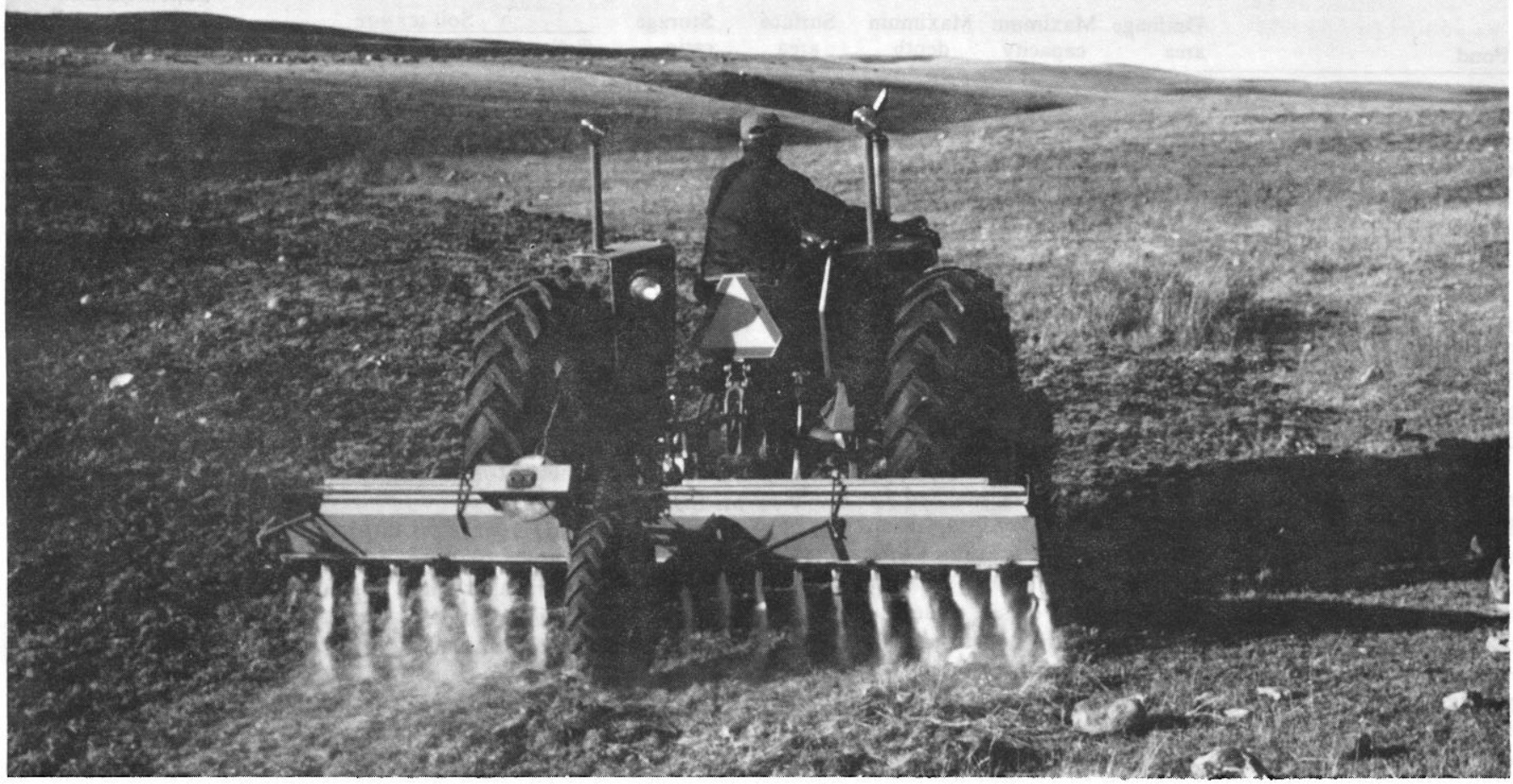

Fig. 2. Spreading sodium carbonate with calibrated fertilizer spreader.

seepage and evaporation losses during these posttreatment years were not different from those in pretreatment years, changes in the treated ponds could be attributed to the treatment.

In 1975, the first year after treatment, sodium carbonate reduced seepage in the three treated ponds to values comparable with those of the untreated ponds (Table 2). However by 1978, the seepage had returned to rates approaching or equal to the pretreatment values.

These results are very similar to those obtained by $\mathrm{Mr}$. Walter Steingruber, a rancher near Willow Creek, Montana. In the fall of $1974, \mathrm{Mr}$. Steingruber applied sodium carbonate at a rate of 7.4 metric tons/hectare to a stock pond built on fractured limestone and lined with a 30$\mathrm{mm}(1 \mathrm{ft})$ blanket of kaolinite clay from a nearby deposit. Snowmelt filled this pond to a depth of about $2.5 \mathrm{~m}$ in the spring of 1975. Within one month, the pond lost about 1.3 $\mathrm{m}$, but then it stabilized and contained about $0.6 \mathrm{~m}$ in November. The performance in 1976 was similar except that

Table 2. Seepage rates $(\mathrm{mm} /$ day $)$ at $2-\mathrm{m}$ stage.

\begin{tabular}{lccccc}
\hline \hline & \multicolumn{5}{c}{ Pond } \\
\cline { 2 - 6 } Year & Nikolaisen & \multicolumn{3}{c}{ Nikolaisen' $^{1}$} \\
\hline 1972 & A & Morstad & C & Carlson' & Wagner $^{1}$ \\
1973 & 7 & 8 & 28 & 31 & 17 \\
1974 & NR $^{2}$ & NR & NR & NR & NR \\
1975 & 7 & 9 & 28 & 32 & 13 \\
1976 & 7 & 9 & 9 & 6 & 7 \\
1977 & 8 & 8 & 13 & 20 & 9 \\
1978 & NR & NR & NR & NR & NR \\
\hline
\end{tabular}

Pond treated with 6.7 metric tons hectare sodium carbonate in November 1974 $2 \mathrm{NR}=\mathrm{No}$ Record because spring runoff did not fill the reservoirs to the 2-m depth. the pond became dry in the fall, at which time Mr. Steingruber retreated it with sodium carbonate at a rate onehalf the previous rate. The pond held up fairly well in 1977 but Mr. Steingruber reported his intention to treat again at the end of the 1978 grazing season.

\section{Concluding Remarks}

Disking 6.7 metric tons/hectare sodium carbonate into the soil of three farm ponds in eastern Montana effectively reduced seepage losses for about 3 years after treatment. The first year after treatment, seepage rates decreased 60 to $80 \%$ as compared with pretreatment rates, which resulted in an available water supply 7 weeks later than would have been possible without treatment. However, by the fourth year after treatment, seepage rates had increased enough that the treatment could no longer be considered effective. This leads to the conclusion that maintenance applications should be made at 2- to 3-year intervals in order to hold seepage to desirably low rates.

Perhaps Mr. Steingruber's conclusion expresses the results best: "We feel that soda ash may not be the ultimate in pond sealing, but certainly it is the easiest and least costly - which is quite an item - and it surely beats an empty pond."

\section{Literature Cited}

Cooley, K.R., and L.E. Myers. 1973. Evaporation reduction with reflective covers. J. Irrigation Drainage Division 99 (IR3): 353-363. ASCE.

Cooley, K.R. 1975. Evaporation suppression for conserving water supplies. U.S. Dep. Agr., Agr., Res. Serv., W-22, Proc. of the Water Harvesting Symposium, Phoenix, Arizona, March 26-28, 1974. p. 192-200.

Dedrick, A.R. 1975. Storage systems for harvested water. U.S. Dep. Agr., Res. Serv., W-22, Proc. of the Water Harvesting Symposium, Phoenix, Arizona, March 26-28, 1974. p. 175-191. 
Jamison, V.C., and J.F. Thorton. 1963. Sealing farm ponds in Missouri. Univ. of Missouri, Agr. Exp. Sta. Res. Bull. 817.

Laing, I.A.F. 1975. Sealing leaking excavated tanks on farms in western Australia. U.S. Dep. Agr., Agr. Res. Serv., W-22, Proc. of the Water Harvesting Sympsoium, Phoenix, Arizona, March 26-28, 1974. p. 159 169.

Nakayama, F.S. 1966. Deflocculation of soil materials by sodium salts. Soil Sci. 102: 388-393.

Reginato, R.J., L.E. Myers, and F.S. Nakayama. 1968. Sodium carbonate for reducing seepage from ponds. U.S. Dep. Agr., Agr. Res. Serv., Water Conserv. Lab. Report 7.

Reginato, R.J., F.S. Nakayama, and J.B. Miller. 1973. Reducing seepage from stock tanks with uncompacted, sodium-treatment soils. J. Soil and Water Conserv. 28: 214-215.
Roberts, W.J. 1958. Evaporation suppression from water surfaces. Illinois State Water Survey, Circ. 68.

Roberts, W.J. 1959. Reducing lake evaporation in the midwest. Illinois State Water Survey, Circ. 76.

U.S. Bureau of Reclamation. 1959. Water loss investigations: Lake Hefner 1958. Evaporation reduction investigations. Report by the collaborators. U.S. Weather Bureau. 1959. Evaporation maps for the United States. Tech. Paper No. 37.

Wight, J.R., E.L. Neff, and F.H. Siddoway. 1975. Snow management on eastern Montana rangelands. Proc. of Symposium on Snow Management of the Great Plains, Bismarck, North Dakota, July 29, 1975. Publ. No. 73. Research Committee, Great Plains Agricultural Council. p. 138-143. 